\title{
DOI https://doi.org/10.30525/978-9934-26-117-6-6
}

\section{ВІРТУАЛЬНА РЕАЛЬНІСТЬ ЯК ЧИННИК МУЛЬТИКУЛЬТУРАЛЬНОСТІ}

\author{
Сакун А. В. \\ доктор філософських наук, \\ доцент кафедри філософії, політології та українознавства
}

Кадлубович T. I.

кандидат політичних наук,

дочент кафедри філософії, політологї̈ та українознавства

Черняк Д. С.

кандидат соиіологічних наук,

дочент кафедри філософії, політології та українознавства

Київський національний університет технологій та дизайну

м. Київ, Україна

Загальновідомим $є$ те, що у сучасному світі величезного значення набуває віртуальна реальність, яка конструює новий штучний світ «багатоманітно та енергійно» [6, с.4], впливає на свідомість людини, на формування іiї картини світу, певним чином організуючи інформацію, кількість якої зростає у геометричній прогресії. Причому, інформація, яку споживає людина XXI століття, використовуючи новітні технології та технічні засоби, стосується найрізноманітніших галузей знання, дозволяє їй подорожувати світом, орієнтуватися у новинках мистецтва, музики, архітектури, а також може доторкнутися до будь-якої культурної спадщини людства. Все це глобалізує культуру, робить іiі мультикультуральною.

Сучасна філософія намагається осмислити поняття віртуальної реальності у різноманітних теоріях та концепціях, але «стійкого понятійного змісту» поки ще не знайдено [3], термін «віртуальна реальність», зазначають дослідники, охоплює «значне семантичне поле 3 нечіткими межами» [3].

Віртуальна реальність породжується активністю іншої реальності [7], є вторинною та проміжною [3]. За походженням вона суб'єктивна, але існує об'єктивно, за нею можна спостерігати та вона не має ознак натуральної реальності [3]. Разом з тим, родовими властивостями віртуальної реальності є актуальність, оскільки вона існує «тут і зараз» 
[7]; автономність - має власні час, простір та закони існування; інтерактивність - «може взаємодіяти з усіма іншими реальностями як онтологічно незалежна» [7]; перетворюваність, дискретність, символічність, ілюзорність, нереальність, ірреальність, потенційність [3]. «Віртуальна реальність - штучно створене комп'ютерними засобами середовище, до якого можна вступати, змінюючи його зсередини, спостерігаючи трансформації та переживати при цьому реальні відчуття» [8]. Це «новий тип аудіовізуальної реальності, де можна вступати в контакти з іншими людьми та 3 штучними персонажами» [8].

Долучитися до такої реальності можна за допомогою інформаційнокомп'ютерних технологій, які стали головним каналом отримання інформації про світ та події в ньому, посередником у формуванні культури, фактором трансформації системи духовного виробництва. Встановлено, що лише 10-15\% знання набуто людиною за допомогою власного досвіду, все інше - результат їі контакту з «інфосферою», «інформаційним моносвітом» [5], створеним засобами масової комунікації. Ця інфосфера глобальна, універсальна та претендує на тотальність поширення. Інформація при цьому набуває подвійного статусу: актуального та віртуального - «інформація поза взаємодією існує віртуально, тобто в закодованому вигляді, коли її зміст прихований та недоступний» [3].

Прихованість та недоступність робить віртуальну реальність гіперреальністю, яка «будучи абсолютно гомогенізованою, «цифровою», «операціональною», в силу своєї досконалості, своєї контрольованості та своєї несуперечливості заміняє все інше» [1, с. 20]. В віртуальному полі, за висловом Ж.Бодрійяра [1, с. 20], людина може опинитися, якщо «рухаючись від символічного до реального, продовжує рух за межі реальності».

Символізація - одна з базових потреб, притаманна лише людині, «символотворча функція - одна 3 первинних у людській діяльності» $[6$, с. 41]. Символами є слова, зображення, умовні позначки. Символами можуть бути речі, якщо вони вказують на престиж, достаток, статус. Символ невідривно пов'язаний з імітацією, тобто симуляцією, яка є основою гіперреальності.

Віртуальна реальність є симулякром, образом без оригіналу, однією 3 головних властивостей якого $\epsilon$, за Ж.Бодрійяром, - здатність маскувати відсутність справжньої реальності. Такими властивостями володіють «три порядки симулякрів: симулякри природні, натуралістичні, засновані на зображенні, імітації та підробці, гармонійні, оптимістичні і спрямовані на відновлення чи ідеальне запровадження природи за образом Бога; симулякри виробничі, спрямовані на підвищення продуктивності, засновані на енергії, силі, їі матеріальному 
втіленні в машині та всій системі виробництва...; симулякри симуляції, засновані на інформації, моделі, кібернетичній грі, - тотальна операційність, гіперреальність, прагнення до тотального контролю» [2, с. 175].

За принципами віртуальної реальності, вважає А. Флієр [8], побудована фактично вся культура, яка $є$ результатом творчості фантазії, створює різноманітні моделі, образи мистецтва, вигадані світи. Все це відповідає потребі людства у доповненні «реального практичного життя життям ілюзорним» [4], щоб розширювати межі свого досвіду. Віртуальна реальність дозволяє людині будувати власний світ: маніпулювати «предметами, яких немає в реальності - псевдо-речами, симулякрами» [8]; виконувати дії, «які лише імітують реальність» [8]; будувати та поширювати сюжетні розповіді, вигадані або які не мають переконливого підтвердження - міфотворчість, де усі внутрішні зв'язки $\epsilon$ імітацією соціальних зв'язків світу людини, а сама ця псевдо-структура збережена у розмаїтті культурних текстів: філософських, богословських, гуманітарних, літературних, мистецьких, музичних, кінематографічних, комп'ютерних тощо.

Телебачення, Інтернет, новітні технології допомагають людині «подорожувати» віртуальною реальністю. Фрагментарність, інтертекстуальність, симуляція, плюралістичність телебачення дозволяє конструювати особливий простір, структурувати його за допомогою певних відрізків часу, фрагментувати життя людини, подаючи інформацію мозаїчно, створюючи телеміфи та телеподії. Ж.-П. Сартр навіть пропонує поняття «серійна культура» для позначення специфіки соціального буття під впливом мас-медіа, коли люди об'єднуються віртуально, а суспільство розкладається на «серійні єдності». Використання особливих культурно-історичних кодів, способів передачі текстів вербального та невербального характеру та подальше їх сприйняття позначається як інтертекстуальність - розмиття меж тексту, позбавлення його закінченості та закритості, надання йому внутрішньої неоднорідності та багатоманітності значення. Тому лінійний спосіб мислення замінюється різноспрямованим, глобальним, людина здатна побачити множинність культурних альтернатив. Мережа Інтернету ще більше занурює людину у світ віртуальної реальності, створюючи цілу індустрію культури та дозвілля. Його перевагами є демократичність та доступність, відкритість та динамічність, оперативність та постійні розвиток і оновлення. Він дозволяє швидко передавати та отримувати інформацію без меж та бар'єрів, в режимі реального часу та 3 можливістю отримати зворотній зв'язок. Інтернет долає часову та просторову ізольованість окремих народів та їх культур. 
Основним компонентом віртуальної реальності є інформація [3], зокрема, про соціокультурний досвід та культурні традиції, новітні зразки культури. Передана за допомогою інформаційно-комп'ютерних технологій вона впливає на загальне культурне середовище, визначає існування та функціонування сучасної культури, формує полікультурне суспільство, «глобальне село», за висловом М.Маклюена.

Відбувається розширення меж спілкування, виникає глобальний інформаційний простір, вільний доступ до інформації породжує тенденцію до «синтезації елементів різних культур» [8], оскільки можна отримати знання про будь-які культури світу. Науковці заговорили про «глобалізацію культури», або мультикультуральність, яка виявляється не лише на рівні поп- та масової культури, але й надає можливість «споживати» зразки високої культури усім представникам людства, незалежно від їх місця проживання, рівня доходів, статусів. Звичайно, глобалізація як культурне явище має свої позитивні та негативні сторони. Негативним є поглинання національних культур культурами інших країн, уніфікація культур, втрата національної самобутності і ідентичності, масовизація культури. Позитивними наслідками глобалізації є ліквідація варварства, підвищення рівня освіченості та загальної культури. Мультикультуральність передбачає адаптацію та шанобливе ставлення до культурних традицій, взаємодію між носіями цих традицій на принципах толерантності та взаємоповаги; відмову та запобігання проявів культурної монополії, ворожості одних націй i народів стосовно інших. Поширення мультикультуральності відбувається завдяки мобільності інформації, яка забезпечується сучасними інформаційними і комунікаційними технологіями, а також засобами масової інформації.

Наукова проблематика мультикультуралізму досить багатоманітна, а тому вимагає подальшого вивчення 3 метою створення нової парадигми філософії культури.

\section{Лiтература:}

1. Бодрийяр Ж. Пароли. От фрагмента к фрагменту. Екатеринбург: У-Фактория, 2006. 199 с.

2. Бодріяр Ж. Симулякри і симуляція Київ: Видавництво Соломії Павличко «Основи», 2004. 230 с.

3. Грязнова Е.В. Философский анализ концепций виртуальной реальности. Философская мыслль. 2013. № 4. С. 53 - 82 . URL: https://nbpublish.com/library_read_article.php?id=278 (дата звернення: 01.07.21)

4. Каган М. С. Философия культуры. Спб.: Петрополис, 1996. 414 с. 
5. Кушхова А. М. Влияние массовой культуры на социокультурную адаптацию URL: https://cyberleninka.ru/article/n/vliyanie-massovoy-kultury-na-sotsiokulturnuyu-adaptatsiyu (дата звернення: 08.07.21)

6. Лангер С. Философия в новом ключе: Исследование символики разума, ритуала и искусства. Москва: Республика, 2000. 287 с.

7. Носов Н.А. Словарь виртуальных терминов. Труды лаборатории виртуалистики. Выпуск 7, Труды Центра профориентации. Москва: «Путь», 2000. 69 c. URL: http://www.virtualistika.ru/vip_7_0.html (дата звернення: 07.07.21)

8. Флиер А.Я. Некультурные функции культуры. Очерки. Москва: МГУКИ, 2008. 272 с. 